Received: 7 February 2017

Accepted: 12 June 2017

Published online: 21 July 2017

\section{Tumor-targeted delivery of siRNA using fatty acyl-CGKRK peptide conjugates}

\author{
Meenakshi Sharma ${ }^{1}$, Naglaa Salem El-Sayed (iD ${ }^{1,2}$, Hung Do¹, Keykavous Parang1 , Rakesh \\ Kumar Tiwari ${ }^{1}$ \& Hamidreza Montazeri Aliabadi ${ }^{1}$
}

Tumor-targeted carriers provide efficient delivery of chemotherapeutic agents to tumor tissue. CGKRK is one of the well-known tumor targeting peptides with significant specificity for angiogenic blood vessels and tumor cells. Here, we designed fatty acyl conjugated CGKRK peptides, based on the hypothesis that hydrophobically-modified CGKRK peptide could enhance cellular permeation and delivery of siRNA targeted to tumor cells for effective silencing of selected proteins. We synthesized six fatty acyl-peptide conjugates, using a diverse chain of saturated and unsaturated fatty acids to study the efficiency of this approach. At peptide:siRNA weight/weight ratio of $10: 1$ (N/P $\approx 13.6$ ), almost all the peptides showed complete binding with siRNA, and at a w/w ratio of 20:1 (N/P $\approx 27.3$ ), complete protection of siRNA from early enzymatic degradation was observed. Conjugated peptides and peptide/ siRNA complexes did not show significant cytotoxicity in selected cell lines. The oleic acid-conjugated peptide showed the highest efficiency in siRNA uptake and silencing of kinesin spindle protein at peptide:siRNA $w / w$ ratio of 80:1 (N/P $\approx 109)$. The siRNA internalization into non-tumorigenic kidney cells was negligible with all fatty acyl-peptide conjugates. These results indicate that conjugation of fatty acids to CGKRK could create an efficient delivery system for siRNA silencing specifically in tumor cells.

Despite significant advances in cancer research and introduction of new generations of molecularly-targeted drugs, cancer is still among leading causes of morbidity worldwide. In fact, more than 14 million of new cases of cancer were diagnosed in 2012, and more than 8 million cancer-related deaths were reported in the same year ${ }^{1}$. American Cancer Society's estimated number of new cases of breast cancer alone in 2016 is approximately 250,000 , and the number of deaths caused by this type of cancer is estimated to exceed 40,000 this year in the US alone ${ }^{2}$. Since the first reports on the possibility of interfering with post-transcription process of protein synthesis using double stranded $\mathrm{RNA}^{3}$, RNA interference (RNAi) has been considered a promising alternative approach in cancer therapy. Different approaches to RNAi have been studied, including small interfering RNA (siRNA). Double stranded siRNA is approximately 20-23 nucleotides long, and the antisense strand directs the RNA-induced silencing complex (RISC) to the targeted mRNA. Argonaute 2, a component of RISC, degrades the target mRNA by its ribonuclease activity, and degradation of mRNA suppresses the expression of the target protein ${ }^{4-7}$. siRNA silencing is highly specific for the selected $\operatorname{target}^{8}$. Despite advantages of siRNA silencing, there are still several impediments that restrict the use of siRNA in cancer therapy. The main obstacles are the short stability of siRNA under physiological conditions, as siRNA gets readily degraded by the nucleases in the serum ${ }^{9}$, and the negligible cellular internalization due to anionic and hydrophilic nature of the double stranded RNA.

Considering all these barriers, designing a safe and efficient siRNA delivery system is required. Different strategies have been explored for siRNA delivery, which includes specifically designed polymers ${ }^{10-12}$, antibodies $^{13}$, aptamers ${ }^{14}$, lipids ${ }^{15-17}$, and peptides ${ }^{18,19}$; however, despite occasional promising efficacy in vitro, they have mostly proven less than optimal for efficient in vivo delivery. Additionally, a promising approach to improve the nucleic acid delivery into the target cells is to incorporate a hydrophobic moiety onto poly cationic polymers ${ }^{20}$. It is reported that, the coupling of different fatty acids with polycationic polymers could increase the $\zeta$-potential

${ }^{1}$ Center for Targeted Drug Delivery, Department of Biomedical and Pharmaceutical Sciences, Chapman University School of Pharmacy, Harry and Diane Rinker Health Science Campus, Irvine, California, 92618, United States. ${ }^{2}$ Cellulose and Paper Department, National Research Center, Dokki, 12622, Cairo, Egypt. Correspondence and requests for materials should be addressed to R.K.T. (email: tiwari@chapman.edu) or H.M.A. (email: montazer@ chapman.edu) 


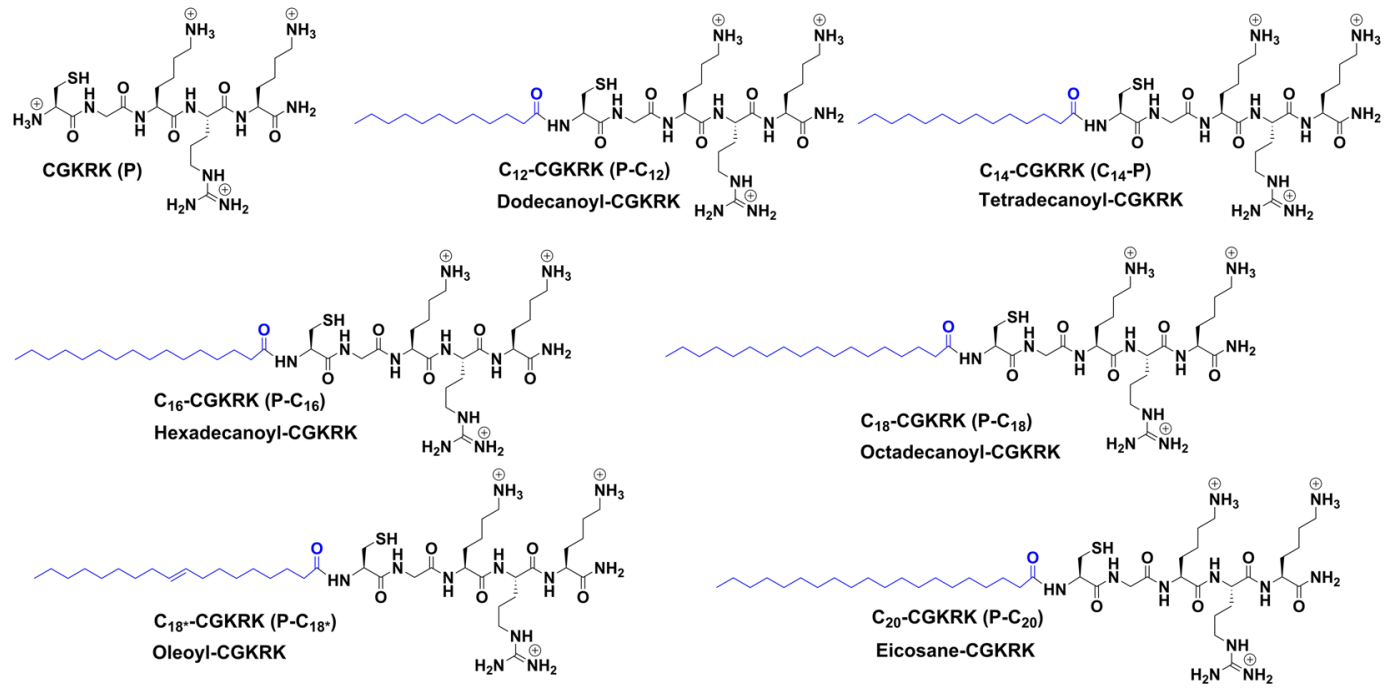

Figure 1. Chemical structures of synthesized fatty acyl-peptide conjugates used in this study.

towards positive values ${ }^{12}$, and enhance the transfection efficiency of the polymer by improving the ability of the polymer to penetrate the cells, and increase the stability of the nucleotide ${ }^{21-23}$. Since the hydrophobic moiety is believed to increase the vector interaction with the lipophilic cell membrane, it is speculated that increasing the hydrophobicity of the carrier could potentially facilitate cellular uptake. For this study, our goal was to combine the tumor specificity of CGKRK peptide, with the affinity of fatty acids to interact with the cell membrane, and create an effective siRNA carrier.

CGKRK is a tumor homing peptide, discovered by phage display technique. It mediates the cellular internalization in energy and heparin sulfate receptor-dependent manner ${ }^{24}$. Then it localizes to mitochondria in cells. CGKRK peptide exhibited selective high binding affinity to the neovascular endothelial cells and tumor tissues, but not to the non-tumorigenic cells ${ }^{25,26}$. The unmodified CGKRK peptide has not been studied as the sole carrier for siRNA delivery. Additionally, a promising approach to improve the nucleic acid delivery into cells is to incorporate a hydrophobic moiety to increase permeation to the cellular membrane ${ }^{7}$. Therefore, we hypothesized that the coupling of an optimized fatty acyl chain with CGKRK peptide can improve the ability of the peptide to permeate and deliver siRNA inside the cancer cell to enhance gene silencing efficiency.

In this study, we conjugated six different fatty acids with increasing number of methylene $\left(\mathrm{CH}_{2}\right)$ in the chain, namely lauric acid, myristic acid, palmitic acid, oleic acid, stearic acid, and arachidic acid to CGKRK peptide (Fig. 1) and evaluated the impact of the conjugation on the efficiency of the peptide in siRNA delivery to the tumor cells. Fatty acyl-peptide conjugates were purified and characterized using reverse-phase high-pressure liquid chromatography (RP-HPLC) and high-resolution matrix-assisted laser desorption/ionization time-of-flight (MALDI-TOF/TOF) mass spectrometer, respectively. We further characterized and evaluated conjugated peptides by selected parameters i.e. size and zeta potential, siRNA binding, serum stability, specificity for the cancer cells, cellular uptake, and most significantly, the mRNA interference efficacy. To test the conjugated peptides, we used 3 different cancer cells lines (AU-565, a human breast cancer cell line; MDA-MB-435, a human cancer cell line considered a breast cancer cell line for many years, and recently recognized as a melanoma cell line; and MDA-MB-231, a triple negative human breast cancer cell line) and one non-tumorigenic human cell line (human embryonic kidney cells; HEK-293) to observe the specificity of the peptide for the cancer cells.

\section{Materials and Methods}

Materials. All required organic solvents and fatty acids were purchased from Wilkem Scientific (Pawtucket, RI, USA). Coupling reagents, Rink amide MBHA resin, and Fmoc-amino acid building blocks were purchased from Chem-Impex International Inc. (Wood Dale, IL, USA). 3-(4,5-Dimethylthiazol-2-yl)-2,5-diphenyltetrazolium bromide (catalog \# M2128) was from Sigma (St. Louis, MO). Hanks balanced salt solution (HBSS), Dulbecco's modified Eagle medium (DMEM; low glucose with L-glutamine), RPMI -1640 medium with L-glutamine, fetal bovine serum (FBS), SYBR Green II solution, penicillin $(10000 \mathrm{U} / \mathrm{mL})$, Lipofectamine ${ }^{\circledR} 2000$, and streptomycin $(10 \mathrm{mg} / \mathrm{mL})$ were provided by Life Technologies (Grand Island, NY). Scrambled negative control siRNA (catalog \# AM4635), 5' -carboxyfluorescein (FAM)-labeled negative control siRNA (catalog \# AM4620), and the siRNA targeting kinesin spindle protein (KSP; catalog \# AM16704) were obtained from Ambion (Austin, TX). All the primers were purchased from IDT. Heparin sodium salt from porcine intestinal mucosa was purchased from Alfa Aesar (Ward Hill, MA). PCR master mixes iScript ${ }^{\mathrm{TM}}$ reverse transcription supermix and iTaq universal SYBR ${ }^{\circledR}$ Green supermix were purchased from Bio-Rad (Hercules, CA). Ethylenediaminetetraacetic acid (EDTA) and all other requirements were provided by Fisher Scientific (Carlsbad, CA).

Cell lines. The human cancer cell lines, MDA-MB-231, MDA-MB-435, and AU565 were purchased from American Type Culture Collection (ATCC; Manassas, VA). The human embryonic kidney 293 (HEK293) cell 


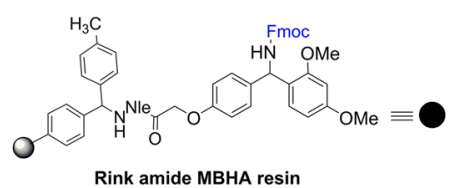

Rink amide MBHA resin
1. $20 \%$ Piperidine in DMF

2. Fmoc-Lys(Boc)-OH/HBTU/DIPEA

3. Repeat Step 1 and Fmoc-Arg(Pbf)-OH/HBTU/DIPEA

4. Repeat Step 1 and 2 .

5. Repeat Step 1 and Fmoc-Gly-OH/HBTU/DIPEA 6. Repeat Step 1 and Fmoc-Cys(Trt)-OH/HBTU/DIPEA 7. Repeat Step 1.
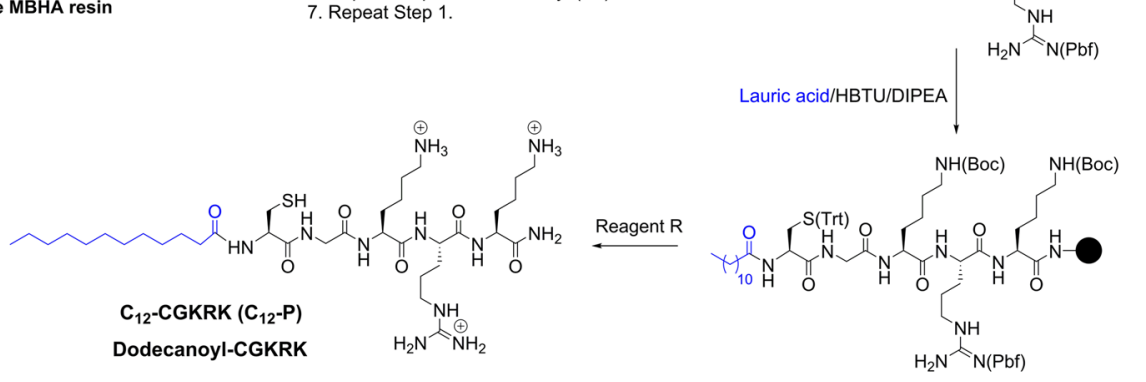

Figure 2. Synthesis of Dodecanoyl-CGKRK as a Representative Example.

line was a gift from Dr. Keykavous Parang's laboratory. MDA-MB-231 was cultured in DMEM medium, and MDA-MB-435 and AU-565 were grown in RPMI-1640 medium. Both media were supplemented with 10\% (v/v) fetal bovine serum, $100 \mathrm{U} / \mathrm{mL}$ penicillin and $100 \mu \mathrm{g} / \mathrm{ml}$ streptomycin. Cells were maintained at normal condition of $37^{\circ} \mathrm{C}$ and $5 \% \mathrm{CO}_{2}$ under humidified atmosphere.

Synthesis and characterization of fatty acyl-peptide conjugates. In general, the peptide was synthesized by the solid-phase synthesis strategy employing $N$-(9-fluorenyl)methoxycarbonyl (Fmoc)-based chemistry and Fmoc-L-amino acid building blocks, under nitrogen at room temperature as described by $\mathrm{Oh}$ et al. ${ }^{27}$. All the synthesized fatty acyl peptides and the unmodified peptide were purified by reversed-phase Hitachi HPLC (L-2455) equipped with a Waters XBridgeTM BEH130 prep C18 column with OBDTM $10 \mu \mathrm{m}$ $(19 \mathrm{~mm} \times 250 \mathrm{~mm})$. The purification was carried out at $10.0 \mathrm{~mL} / \mathrm{min}$ flow rate using a gradient of $0-100 \%$, acetonitrile ( $0.1 \%$ TFA) and water $(0.1 \%$ TFA) over $60 \mathrm{~min}$. High-resolution MALDI-TOF/TOF mass spectrometers (ABX SCIEX TOF/TOF and Bruker autoflex speed MALDI-TOF/TOF) were used to confirm the structure of the peptide conjugate in the purified fraction. A solution of $\alpha$-cyano-4-hydroxycinnamic acid $(5 \mathrm{mg} / \mathrm{ml})$ in acetonitrile $(0.1 \%$ TFA $)$ and water $(0.1 \%$ TFA $)(1: 1, v / v)$ was freshly prepared as the matrix. An aliquot of the sample was mixed with the matrix at the ratio of 1:3 and spotted onto the MALDI plate, and was air dried in the dark for few min before the analysis. The purified peptide fractions were pooled, evaporated, and kept in $-80^{\circ} \mathrm{C}$ refrigerator overnight and then lyophilized for $48 \mathrm{~h}$ to get powdered peptide for further assays. The lyophilized peptides were stored in $-20^{\circ} \mathrm{C}$ refrigerator until their use in the assay. The mass of the compounds was confirmed by high-resolution MALDI- TOF/TOF mass spectrometers.

As a representative example, the synthesis of dodecanoyl-CGKRK is described here (Fig. 2). The linear peptide sequence CGKRK was synthesized using Tribute automated peptide synthesizer (Protein Technology, Inc., Arizona), in $0.40 \mathrm{mmol}$ scale. The Rink amide MBHA resin (loading $0.52 \mathrm{mmol} / \mathrm{g}, 770 \mathrm{mg}$ ) was swelled for approximately 30 min under anhydrous DMF with the help of dry nitrogen in glass vessel fitted with frit (manual peptide synthesis vessel). All coupling and deprotection steps were carried out at room temprature. The solvent was filtered off using a vacuum, and the swelling and filtration steps were repeated two more times before resin was transferred to the tribute peptide synthesizer vessel to start automated peptide synthesis. To assemble linear peptide sequence, the synthesis was started using building block amino acids containing side chain and Fmoc protection, such as Fmoc-Lys(Boc)-OH (468 mg, $1 \mathrm{mmol}$ ), Fmoc-Arg(Pbf)-OH (648.77 mg, $1 \mathrm{mmol})$, Fmoc-Lys(Boc)-OH (468 mg, $1 \mathrm{mmol})$, Fmoc-Gly-OH (297.31 mg, $1 \mathrm{mmol})$, and Fmoc-Cys(Trt)-OH (585.71 mg, $1 \mathrm{mmol}$ ), using DMF as solvent and 2-(1H-benzotriazole-1-yl)-1,1,3,3-tetramethyluranium hexafluorophosphate (HBTU, $1 \mathrm{mmol}$ ), and 0.4 M N-methyl morpholine in DMF as coupling, and activating reagents, respectively. The Fmoc deprotection at each step was carried out using piperidine in DMF $(20 \% \mathrm{v} / \mathrm{v})$. After the linear peptide was assembled, the peptidyl-resin was transferred to a manual peptide synthesis vessel. A solution of lauric acid ( $200 \mathrm{mg}$, $1 \mathrm{mmol}$, dissolved in DCM/DMF mixture) was added to the mixture, and then activated using HBTU (379 mg, $1 \mathrm{mmol}$ ) and DIPEA (4 molar equivalent, $697 \mu \mathrm{L}$ ) with vortexing for $10 \mathrm{~min}$. The mixture was agitated using nitrogen for $24 \mathrm{~h}$ at room temperature. Afterward, the resin was washed several times with DMF ( 3 times, $10 \mathrm{~min}$ each), DCM ( 3 times, $10 \mathrm{~min}$ each), and acetone ( 3 times, $10 \mathrm{~min}$ each) and dried. The peptide was cleaved from the resin, and the side chains protection were removed by agitating in freshly prepared cleavage cocktail using "Reagent R" (20 mL, TFA:thioanisole:1,2-ethanedithiol:anisole, 92:5:3:2, v/v/v/v) at room temperature for $6 \mathrm{~h}$. The crude dodecanoyl-CGKRK was precipitated by adding cold diethyl ether $\left(\mathrm{Et}_{2} \mathrm{O}, 50 \mathrm{~mL} \times 2\right.$ times $)$ and centrifuged for $10 \mathrm{~min}$. The precipitate was collected, dissolved in acetonitrile $(0.1 \% \mathrm{TFA})$ with the help of few drops of water (0.1\% TFA), and purified by reversed-phase Hitachi HPLC (L-2455) equipped with a Waters XBridgeTM BEH130 prep C18 column with OBDTM $10 \mu \mathrm{m}(19 \mathrm{~mm} \times 250 \mathrm{~mm})$. The purification was carried out at $10.0 \mathrm{~mL} / \mathrm{min}$ flow rate using a gradient of $0-100 \%$, acetonitrile $(0.1 \%$ TFA) and water $(0.1 \%$ TFA) over 60 min. High-resolution MALDI-TOF/TOF mass spectrometers (ABX SCIEX TOF/TOF and Bruker autoflex speed MALDI-TOF/TOF) were used to confirm the structure of the peptide conjugate in the purified fraction. An aliquot of the sample was mixed with the matrix at the ratio of 1:3 and spotted onto the MALDI plate, and was air dried in the dark for few 
min before the analysis. The purified peptide fractions were pooled, evaporated, and keept in $-80^{\circ} \mathrm{C}$ refrigerator over night and then lyophilized for $48 \mathrm{~h}$ to get powdered peptide for further assays.

CGKRK (P): MALDI-TOF (m/z): $\mathrm{C}_{23} \mathrm{H}_{47} \mathrm{~N}_{11} \mathrm{O}_{5} \mathrm{~S}$ calcd. 589.3482; found $590.6109[\mathrm{M}+\mathrm{H}]^{+}$; Dodecanoyl-CGKRK (P-C12): MALDI-TOF (m/z): $\mathrm{C}_{35} \mathrm{H}_{69} \mathrm{~N}_{11} \mathrm{O}_{6} \mathrm{~S}$ calcd. 771.5153; found $772.2769[\mathrm{M}+\mathrm{H}]^{+}$; Tetradecanoyl-CGKRK (P-C14): MALDI-TOF (m/z): $\mathrm{C}_{37} \mathrm{H}_{73} \mathrm{~N}_{11} \mathrm{O}_{6} \mathrm{~S}$ calcd. 799.5466; found $800.2928[\mathrm{M}+\mathrm{H}]^{+}$; Hexadecanoyl-CGKRK (P-C16): MALDI-TOF (m/z): $\mathrm{C}_{39} \mathrm{H}_{77} \mathrm{~N}_{11} \mathrm{O}_{6} \mathrm{~S}$ calcd. 827.5779; found 828.2538 $[\mathrm{M}+\mathrm{H}]^{+}$; Octadecanoyl-CGKRK (P-C18): MALDI-TOF (m/z): $\mathrm{C}_{41} \mathrm{H}_{81} \mathrm{~N}_{11} \mathrm{O}_{6} \mathrm{~S}$ calcd. 855.6092; found 857.7393 $[\mathrm{M}+2 \mathrm{H}]^{+}$; Oleoyl-CGKRK (P-C18*): MALDI-TOF (m/z): $\mathrm{C}_{41} \mathrm{H}_{79} \mathrm{~N}_{11} \mathrm{O}_{6} \mathrm{~S}$ calcd. 853.5936; found 854.3768 $[\mathrm{M}+\mathrm{H}]^{+}$; Eicosane-CGKRK (P-C20): MALDI-TOF (m/z): $\mathrm{C}_{43} \mathrm{H}_{85} \mathrm{~N}_{11} \mathrm{O}_{6} \mathrm{~S}$ calcd. 883.6405; found 884.3861 $[\mathrm{M}+\mathrm{H}]^{+}$.

Peptide/siRNA complex formation. Peptide/siRNA complexes were formed by simple mixing of siRNA and peptides in different $\mathrm{w} / \mathrm{w}$ ratios, as described in our previous reports ${ }^{11,12}$. First, siRNA was added to $150 \mathrm{mM}$ $\mathrm{NaCl}$ solution. The fatty acid-conjugated peptide was dissolved in double-distilled water at a stock concentration of $2 \mathrm{mg} / \mathrm{mL}$. The peptide solution was added to siRNA/saline mixture at different proportions, and mixed. The complexes were incubated at room temperature for $30 \mathrm{~min}$ for complete complex formation. The complexes were formed using pre-decided peptide:siRNA ratios, which will be specified during the manuscript as both weight/ weight and N/P ratios. Where $\mathrm{w} / \mathrm{w}$ ratio was simply calculated by dividing the total weight of peptide present in the complex solution added to the cells to the weight of siRNA in the same solution, N/P ratio was calculated by equation 1:

$$
\frac{N}{P}=\frac{(\text { Number of moles for peptide } \times \text { Number of Nitrogens })}{\text { Number of moles for siRNA } \times 48}
$$

where 48 represents the average number of phosphates in each siRNA molecule. The N/P ratios mentioned throughout the manuscript is the average of N/P ratios for each individual modified peptide.

Size and $\zeta$-potential of nanoparticles. Peptide/siRNA complexes were prepared with peptide:siRNA weight/weight ratio of $1: 1(\mathrm{~N} / \mathrm{P} \approx 1.4), 5: 1(\mathrm{~N} / \mathrm{P} \approx 6.8), 10: 1(\mathrm{~N} / \mathrm{P} \approx 13.6)$, and $20: 1(\mathrm{~N} / \mathrm{P} \approx 27.3)$. Size and zeta $(\zeta)$ potential of the complexes were measured at least three times each using a Malvern Nano ZS Zetasizer (Westborough, MA). All measurements were performed at $25^{\circ} \mathrm{C}$. Zeta potential of the complexes was determined in a disposable folded capillary cell at a voltage of $40 \mathrm{~V}$ using Smoluchowski approximation.

Binding affinity for siRNA. The binding affinity of the peptide to siRNA was investigated by SYBR Green II dye exclusion assay, as we have reported previously ${ }^{12}$. Briefly, scrambled siRNA solutions were prepared in RNase-free water $(0.5 \mu \mathrm{g} / \mathrm{ml})$, and peptide/siRNA complexes were prepared with w/w ratios of 0.125:1 $(\mathrm{N} / \mathrm{P} \approx 0.17), 0.317: 1(\mathrm{~N} / \mathrm{P} \approx 0.43), 0.625: 1(\mathrm{~N} / \mathrm{P} \approx 0.85), 1.25: 1(\mathrm{~N} / \mathrm{P} \approx 1.7), 2.5: 1(\mathrm{~N} / \mathrm{P} \approx 3.4), 5: 1(\mathrm{~N} / \mathrm{P} \approx 6.8)$, and $10: 1(\mathrm{~N} / \mathrm{P} \approx 13.6)$ (with free siRNA as control). After $30 \mathrm{~min}$ incubation at room temperature, $200 \mu \mathrm{l}$ of SYBR Green II solution (1:10,000 dilution in water) was added to the complexes. The fluorescence of the samples was quantified in a 96 -well black plates ( $\lambda$ excitation: $485 \mathrm{~nm}, \lambda$ emission: $527 \mathrm{~nm}$ ) to determine the proportion of unbound siRNA. The percentage of siRNA bound to the peptide was plotted against the peptide/siRNA ratio, and the ratio required for $50 \%$ binding (BC50) was calculated based on the line equation of the linear portion of the curve under these experimental conditions.

Serum stability of peptide-bound siRNA. Complexes of peptide/siRNA were prepared using scrambled siRNA and the synthesized peptides with the w/w ratios of 5:1 (N/P $\approx 6.8), 10: 1(\mathrm{~N} / \mathrm{P} \approx 13.6), 20: 1(\mathrm{~N} / \mathrm{P} \approx 27.3)$, and $40: 1(\mathrm{~N} / \mathrm{P} \approx 54.6)$, using free siRNA as a positive control. Complexes were incubated in triplicates at $37^{\circ} \mathrm{C}$ in a $25 \% \mathrm{v} / \mathrm{v}$ FBS solution in HBSS for $24 \mathrm{~h}$. At the end of incubation period, heparin $(2 \mu \mathrm{l}$ of $5 \%$ solution in normal saline) and EDTA ( $3 \mu \mathrm{l}$ of $0.5 \mathrm{mM}$ solution) were added to the samples for complete dissociation of the siRNA from the complexes. The samples were analyzed on a $1 \%$ agarose gel containing $1 \mu \mathrm{g} / \mathrm{mL}$ ethidium bromide at $70 \mathrm{~V}$ for $20 \mathrm{~min}$. The gel was visualized under UV illumination (Gel-Doc system, Bio-Rad; Hercules, CA), and the intensity of the bands corresponding to the remaining intact siRNA was quantified using Image J software.

Cytotoxicity of peptides and peptide/siRNA complexes. The cytotoxicity of the delivery system was investigated in different human cancer cell lines (AU565, MDA-MB-231, and MDA-MB-435) and a human non-tumorigenic kidney cell line (HEK293 cells) after exposure to peptides alone, or in complex with siRNA. Confluent cell cultures $(\sim 600,000-800,000$ cells $/ \mathrm{mL})$ were trypsinized and seeded in 96 well plates with $100 \mu \mathrm{l}$ of the medium in each well, and allowed to reach $\sim 50 \%$ confluency in $24 \mathrm{~h}$. Peptides were added to the wells at a final concentration of $20 \mu \mathrm{g} / \mathrm{mL}, 40 \mu \mathrm{g} / \mathrm{mL}$, and $80 \mu \mathrm{g} / \mathrm{mL}$ in triplicate. Peptide/siRNA complexes were prepared using scrambled siRNA (final concentration of $36 \mathrm{nM}$ in cell media) at a w/w ratio of 20:1 (N/P $\approx 27.3), 40: 1$ $(\mathrm{N} / \mathrm{P} \approx 54.6)$ ) and $80: 1(\mathrm{~N} / \mathrm{P} \approx 109)$ (which translate to $10.3,20.6$, and $41.2 \mu \mathrm{g} / \mathrm{mL}$ final concentration, respectively). After $72 \mathrm{~h}$ incubation at $37^{\circ} \mathrm{C}$ and regular cell culture conditions, $20 \mu \mathrm{l}$ of 3-(4,5-dimethylthiazol-2-yl)2,5-diphenyltetrazolium bromide (MTT) solution $(5 \mathrm{mg} / \mathrm{mL}$ in HBSS) was added to each well. After $45 \mathrm{~min}$ of incubation at $37^{\circ} \mathrm{C}$, the medium was removed, and the formazan crystals that formed were dissolved in $100 \mu \mathrm{l}$ of DMSO per well. The absorbance at $570 \mathrm{~nm}$ was measured with Spectra Max M5 plate-reader (Molecular Devices; Sunnyvale, CA) with no dye added to three wells as blank. The relative cell viability was calculated and expressed as a percentage relative to untreated cells.

Cellular Internalization. Confluent cell cultures were seeded in 24-well plates at 200,000 cells $/ \mathrm{mL}$. Peptide/siRNA complexes were prepared using FAM-labeled scrambled siRNA with peptide:siRNA w/w ratios 
of $20: 1(\mathrm{~N} / \mathrm{P} \approx 27.3), 40: 1(\mathrm{~N} / \mathrm{P} \approx 54.6)$ ) and 80:1 (N/P $\approx 109)$ (corresponding to $36 \mathrm{nM}$ siRNA and $\sim 10,20$ and $40 \mu \mathrm{g} / \mathrm{mL}$ peptide in culture media, respectively) and were added to the cells after $24 \mathrm{~h}$ of seeding. After $24 \mathrm{~h}$ of incubation at $37^{\circ} \mathrm{C}$, the cells were washed with HBBS, trypsinized, and fixed with $3.7 \%$ formaldehyde solution. The siRNA uptake was quantified by Flow cytometer (BD-FACSVerse, BD Biosciences; San Jose, CA) using FITC channel to detect the cell-associated fluorescence signal. The percentage of cells showing FAM fluorescence and the mean fluorescence in the selected cell population were determined. Calibration was performed by gating with the negative control (i.e., "No Treatment") group, so that the auto-fluorescent cells represented $\sim 1 \%$ of the total cell population.

For fluorescence microscopy, cells were seeded in 24 well plates at $\sim 400,000$ cells $/ \mathrm{mL}$. After $24 \mathrm{~h}$, similar peptide/siRNA complexes (prepared at a peptide:siRNA w/w ratio of 80:1 (N/P $\approx 106$ with $\left.\mathrm{P}-\mathrm{C} 18^{*}\right)$ were added to the cells. After $24 \mathrm{~h}$ of incubation at $37^{\circ} \mathrm{C}$, the cells were washed with HBBS and fixed with $3.7 \%$ formaldehyde. Cell membrane and nucleus were stained with Texas Red Phalloidin (Invitrogen) (1:250 in HBSS) and DAPI and incubating the cells for $1 \mathrm{~h}$ and $5 \mathrm{~min}$, respectively and consecutively, at room temperature, followed by washing with HBSS. Keyence BZ-X700 all-in-one Fluorescence Microscope (KEYENCE Corp. of America, Itasca, IL) was used to take fluorescence images using the 20x objective and different filters for DAPI, FITC, and Texas Red. Untreated cells and cells exposed to free siRNA were used as negative control.

Interference with model mRNA and Real-Time PCR. Confluent AU565 cell cultures were seeded in 6-well plates at $\sim 400,000$ cells/mL for mRNA analysis by real-time PCR. Peptide:siRNA complexes were prepared using scrambled siRNA (as a negative control) or KSP siRNA, with a w/w ratio of $80: 1(\mathrm{~N} / \mathrm{P} \approx 109)$ and final siRNA concentration of $54 \mathrm{nM}$. As a positive control, a group of cells were exposed to the same concentration of siRNA delivered by Lipofectamine ${ }^{\circledR} 2000$, using the instructions provided by the manufacturer. Complexes were added to the cells, and cells were incubated for $48 \mathrm{~h}$ at $37^{\circ} \mathrm{C}$. Cells were then lysed with TRIzol ( $1 \mathrm{~mL}$ for each $1 \times 10^{6}$ cells $)$ and incubated at room temperature for $5 \mathrm{~min}$. Chloroform $(0.2 \mathrm{~mL}$ for each $\mathrm{mL}$ of TRIzol $)$ was added to the lysates, and the aqueous phase was separated after shaking and 2-3 min incubation at room temperature. Isopropanol was used to precipitate RNA and the pellet was washed with $75 \%$ ethanol. Extracted RNA was then dissolved in RNase-free water, and the total RNA was determined by BioSpec-Nano (Shimadzu, Columbia, MD). RNA $(0.5 \mu \mathrm{g})$ was reverse transcribed to synthesize cDNA using iScriptTM reverse transcription supermix and the $\mathrm{C} 1000$ Touch $^{\circledR}$ thermocycler (Bio-Rad, Hercules, CA) according to the manufacturer's guidelines. A CFX96 ${ }^{\mathrm{TM}}$ optical module (Bio-Rad, Hercules, CA) was used for RT-PCR analysis using human $\beta$-actin as the endogenous gene. Primers were designed using primer Blast software available at The National Center for Biotechnology Information website (http://www.ncbi.nlm.nih.gov/) and were synthesized with the following sequences by the IDT Technologies (Coralville, Iowa): $\beta$ - Actin (Forward: $5^{\prime}$-CCA CCC CAC TTC TCT CTA AGG A-3'; Reverse: 5'-AAT TTA CAC GAA AGC AAT GCT-3') and KSP (Forward: $5^{\prime}$-TCA CAA AAG CAA TGT GGA AAC CTA-3'; Reverse: 5'-TCT GTC CAA AGA TTCA TTA ACT TGC A-3'). Primers were tested to assure equal efficiency at different cDNA concentrations (with a slope $<0.1$ for the $\Delta \mathrm{CT}$ vs. $\mathrm{cDNA}$ dilution graph) and selectivity for the mRNA of interest. Analysis was performed by calculating $\Delta \mathrm{CT}, \Delta \Delta \mathrm{CT}$, and relative quantity (RQ) using endogenous gene and "no treatment" group as reference points.

Statistical methods. The significance of the differences observed in siRNA uptake, mRNA levels (analyzed by RT-PCR), and cell viability were evaluated using Student's t-test (with $\mathrm{p}<0.05$ considered significant). Two-way analysis of variance (ANOVA) was used to compare multiple groups followed by Bonferroni post hoc test. Standard deviations were calculated for all results shown and are represented by the error bars in all figures. Pearson's correlation coefficient was calculated where indicated, and its significance was determined by the t-test, according to the equation 2 :

$$
t=r \sqrt{\frac{n-2}{1-r^{2}}}
$$

where $\mathrm{r}$ and $\mathrm{n}$ are the correlation coefficient and the number of samples, respectively. The calculated value of $\mathrm{t}$ was compared to $\mathrm{p}$ values for each degree of freedom to determine the significance of the correlation.

\section{Results}

Synthesis and characterization of fatty acyl-CGKRK peptides. The peptides used in the study (Fig. 1) were synthesized using Fmoc/tBu solid phase chemistry. After assembly of CGKRK peptide, fatty acyl chains with various length (C12-C20) were incorporated at $\mathrm{N}$-terminal during solid-phase peptide chemistry, following the method described by Oh et al. ${ }^{27}$, using commercially available fatty acids namely lauric acid (saturated acid, C-12), myristic acid (saturated acid, C-14), palmitic acid (saturated acid, C-16), stearic acid (saturated acid, C-18), oleic acid (unsaturated fatty acid, C-18), and arachidic acid (saturated acid, C-20) and HBTU/DIPEA as coupling and activating reagents, respectively. Fatty acyl conjugated peptide were cleaved from the solid support using freshly prepared cleavage cocktail reagent $\mathrm{R}$ followed by purification using HPLC and characterized by MALDI mass spectrometry (See Supporting Information). The purity of peptide was found to be $>95 \%$. As a representative example, the synthesis of dodecanoyl-CGKRK conjugate is shown in Fig. 2.

Size and surface charge of the Peptide-siRNA complexes. The effect of peptide structure and peptide:siRNA ratio on the hydrodynamic size and surface charge of the particles were analyzed. The results are summarized in Fig. 3A and B. The size of most of the peptide/siRNA complexes were in the range of 200 to $400 \mathrm{~nm}$, with the exception of the peptide/siRNA ratio of $1: 1(\mathrm{~N} / \mathrm{P} \approx 1.4)$ that resulted in larger complexes $(>800 \mathrm{~nm})$ for all of the fatty acyl-peptide conjugates. Particles formed with the unmodified peptide were relatively small $(180-220 \mathrm{~nm})$. A specific trend in the complex sizes based on the chain length of the fatty acid was not observed 
(Fig. 3A). The siRNA complexes formed with the unmodified peptide showed negative $\zeta$-potential, even at the highest studied peptide/siRNA ratio $(20: 1 ; \mathrm{N} / \mathrm{P} \approx 27.3)$. The fatty acyl-substituted peptides, however, showed a constant increase in the $\zeta$-potential values, and all had a positive surface charge at peptide:siRNA ratios of 5:1 $(\mathrm{N} / \mathrm{P} \approx 6.8)$ and higher (Fig. $3 \mathrm{~B})$. A significant difference was not detected between the surface charges of particles formed with different lipid-substituted peptides, however, the smallest substituted fatty acid (lauric acid, C12) seemed to show higher positive values in ratios of 5:1 $(\mathrm{N} / \mathrm{P} \approx 6.8)$ and higher.

Binding Affinities. The affinity of each peptide to bind to siRNA and form nanoscale complexes was determined by quantifying SYBR green fluorescence (which is magnified as it binds to free siRNA) in triplicate, and the results are summarized in Fig. 3C. Among the studied peptides, the unmodified peptide did not achieve complete binding (even at a peptide:siRNA ratio of $10: 1 ; \mathrm{N} / \mathrm{P} \approx 13.6$ ), and the siRNA binding percentage plateaued at $\sim 50 \%$. The fatty acyl-conjugated peptides, on the other hand, showed almost complete binding at the peptide:siRNA ratio of $5: 1(\mathrm{~N} / \mathrm{P} \approx 6.8)$. After calculating $\mathrm{BC} 50$ for the studied peptides, we analyzed the correlation between the number of methylenes $\left(\mathrm{CH}_{2}\right)$ in the acylated peptide (representing the hydrophobicity of the conjugates) and the BC50, which is illustrated in Fig. 3D. While the BC50 for the arachidic acid-conjugated peptide (C20; the largest fatty acid used) was significantly higher than the other peptides (indicating a lower affinity), and that seemed to be the overall trend, the correlation was not significant $(\mathrm{P}<0.1)$. There was no significant difference in the BC50 calculated for $\mathrm{C} 18$ saturated and unsaturated conjugations (stearic and oleic acids, respectively).

Stability against Enzymatic Degradation. Due to the extreme sensitivity of siRNA to enzymatic degradation (mostly via RNase), we analyzed the stability of siRNA after $24 \mathrm{~h}$ exposure to FBS, to determine the protection afforded by the peptides. Free siRNA exposed to saline and FBS were used as negative and positive controls, respectively. Heparin was added to the complex after the incubation period, to release siRNA from the complexes, and the percentage of intact siRNA (compared to negative control) was determined after for peptide/siRNA ratios of 5:1, 10:1, 20:1, and 40:1 (N/P ratios of 6.8, 13.6, 27.3, and 54.6, respectively) using gel electrophoresis (Fig. 4). Free siRNA was completely degraded, after the incubation period (Fig. 4A). The unmodified peptide did not show any protection, even at a highest ratio of $40: 1(\mathrm{~N} / \mathrm{P} \approx 54.6)$, as there was no intact siRNA detected after $48 \mathrm{~h}$ incubation. With peptide/siRNA ratio of $20: 1(\mathrm{~N} / \mathrm{P} \approx 27.3)$ all fatty acid-substituted peptide showed almost complete protection against degradation except for palmitic acid-conjugated peptide (P-C16; 66\% siRNA detected after $24 \mathrm{~h}$ compared to negative control). At peptide:siRNA ratio of $5: 1(\mathrm{~N} / \mathrm{P} \approx 6.8)$, none of the fatty acylated peptides showed more than $10 \%$ siRNA remaining, except for arachidic acid-conjugated peptide (P-C20), where we detected $\sim 53 \%$ of siRNA remaining. The level of intact siRNA left, constantly increased with the increase in peptide:siRNA ratio for all the studied peptides (Fig. 4B).

Cytotoxicity of Delivery System. The toxicity of the peptides was determined by two approaches: exposing MDA-MB-231, MDA-MB-435, AU-565 (human cancer cell lines), and HEK293 cells (human non-tumorigenic kidney cells) to peptides, or peptide:siRNA complexes. The results are summarized in Fig. 5. We investigated the effect of a wide range of peptide concentrations and peptide:siRNA ratios on cell viability after $72 \mathrm{~h}$ of exposure. In all studied groups, $\sim 80 \%$ or more of the cells were viable, even with highest concentration of peptide alone, or as a complex with siRNA. The only exception was the cells treated with $80 \mu \mathrm{g} / \mathrm{mL}$ of the stearic acid-conjugated peptide in MDA-MB-231 cells, which demonstrated $\sim 67 \%$ viability. A similar effect was observed for this peptide in HEK293 cells (Supplementary Figure 1). No particular trend was detected in the toxicity of the peptides with the alteration of the conjugated fatty acid. Also, a significant difference was not detected between the overall toxicity of the unmodified or modified peptides in different cell lines. Moreover, forming complex with siRNA did not have a significant effect on the toxicity of the studied peptides in any of the included cell lines.

Intracellular Delivery of siRNA. To analyze the impact of fatty acid conjugation to the CGKRK peptide on the siRNA delivery efficiency, different cancer cell lines were used to evaluate fluorescent-labeled siRNA internalization after complex formation with the unmodified and synthesized peptides. The results were evaluated in three cancer cell lines (AU-565, MDA-MB-231, and MDA-MB-435), and a non-tumorigenic human cell line (HEK293) as mean fluorescence and percentage of cells positive for the fluorescence signal, as summarized in Fig. 6 . The unmodified peptide did not create a significant difference in siRNA delivery compared to free siRNA, neither of which were statistically different from not treated (NT) cells. In contrast, the fatty acid-conjugated peptides showed efficiency in siRNA cellular internalization that progressively increased with an increase in peptide:siRNA ratio. At the highest ratio studied $(80: 1 ; \mathrm{N} / \mathrm{P} \approx 109)$, more than $75 \%$ of MDA-MB-435 cells and more than $65 \%$ of AU-565 cells were fluorescent-positive for all modified peptides. Arachidic acid-conjugated peptide (P-C20) showed the highest percentage of siRNA-positive cells in AU-565 with more than $90 \%$ uptake. The 2-way ANOVA for AU-565 cell line showed the siRNA uptake ranking of: $\mathrm{P}-\mathrm{C} 18<\mathrm{P}-\mathrm{C} 12=\mathrm{P}-\mathrm{C} 14=\mathrm{P}-\mathrm{C} 1$ $6<\mathrm{P}-\mathrm{C} 18^{*}<\mathrm{P}-\mathrm{C} 20$. In MDA-MB-435 cells, siRNA uptake exceeded $85 \%$ with both lauric acid and arachidic acid-conjugated peptides, and the ranking for modified peptides was: $\mathrm{P}-\mathrm{C} 16<\mathrm{P}-\mathrm{C} 18^{*}=\mathrm{P}-\mathrm{C} 14<\mathrm{P}-\mathrm{C} 18=\mathrm{P}-\mathrm{C} 12$ $=\mathrm{P}-\mathrm{C} 20$. The overall percentage of fluorescent-positive cells was significantly lower in MDA-MB-231 cells, where only oleic acid and arachidic acid-conjugated peptides (P-C18* and $\mathrm{P}-\mathrm{C} 20$, respectively) were able to internalize siRNA into $\sim 48 \%$ and $\sim 37 \%$ of the cells, respectively (Fig. $6 \mathrm{~A}$ ). The siRNA internalization efficiency ranking among all modified peptides in MDA-MB-231 cells was $\mathrm{P}-\mathrm{C} 12=\mathrm{P}-\mathrm{C} 18<\mathrm{P}-\mathrm{C} 14<\mathrm{P}-\mathrm{C} 16<\mathrm{P}-\mathrm{C} 20<\mathrm{P}-\mathrm{C} 18^{*}$. No significant correlation between the number of $\mathrm{CH}_{2}$ groups in the conjugated fatty acid and the percentage of fluorescent positive cells was observed (data not shown).

The mean fluorescence of the cell population followed a similar trend, and the highest uptake was achieved with peptide:siRNA ratio of $80: 1(\mathrm{~N} / \mathrm{P} \approx 109)$ for each of the modified peptides, with significantly lower values 
A

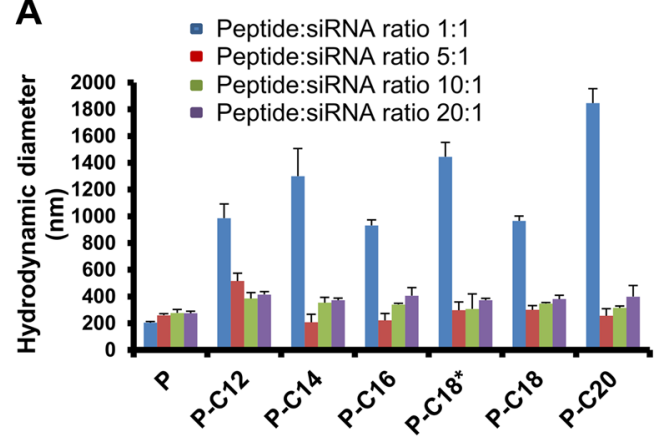

C

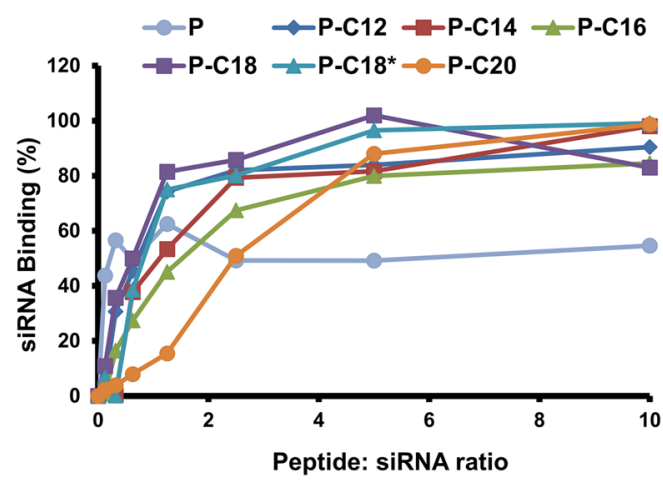

B

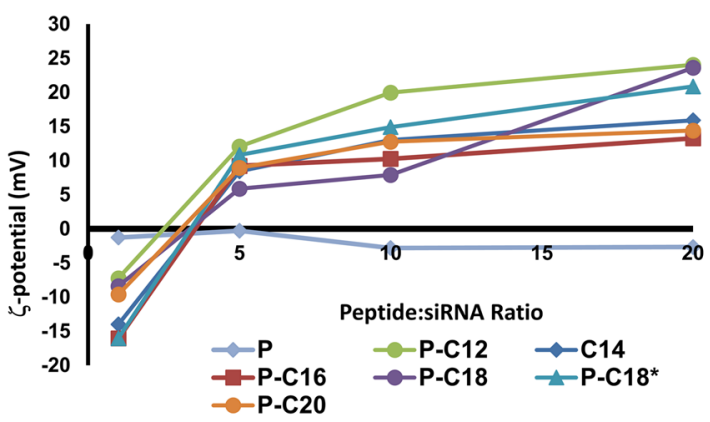

D

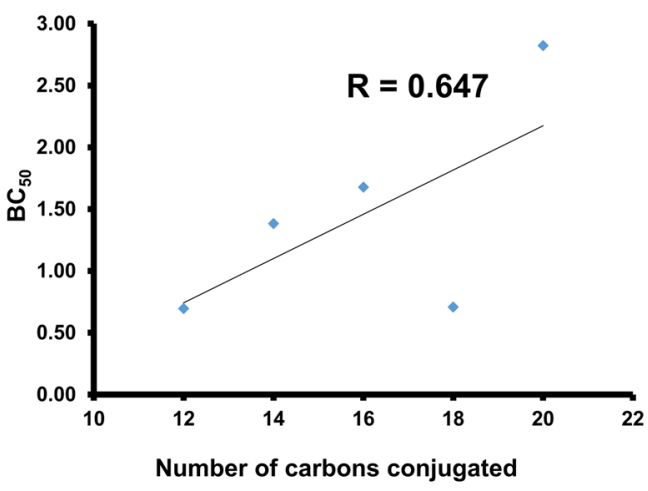

Figure 3. Size, $\zeta$-potential, and binding affinity of designed peptides. (A) Hydrodynamic diameter of native peptide (CGKRK) and the fatty acid conjugated peptides, analyzed by light scattering. A significant drop in the size of particles with increasing the peptide:siRNA w/w ratio to $5: 1(\mathrm{~N} / \mathrm{P} \approx 6.8)$ indicates the complex formation; (B) $\zeta$-potential of the unmodified and the fatty acid-conjugated peptides. A gradual shift to positive surface charge also indicates complex formation with modified peptides. Similar trend was not observed for unmodified CGKRK; (C) Representative graph of Binding affinity of the peptide library to scrambled siRNA, indicating the percentage of siRNA bound to the peptide in different peptide:siRNA w/w ratios. Complete binding was observed for all modified peptides at ratio of 5:1 (N/P $\approx 6.8)$; (D) Correlation between the peptide:siRNA complex ratios required for $50 \%$ binding $\left(\mathrm{BC}_{50}\right)$ and the size of the fatty acid conjugation. $\mathrm{R}=0.647$ indicated a moderate correlation; however, the correlation coefficient was not significant in Pearson correlation coefficient analysis.

A

\begin{tabular}{|c|c|c|c|c|c|c|c|}
\hline P-C20 & P-C18* & P-C18 & P-C16 & P-C14 & P-C12 & $\mathbf{P}$ & \\
\hline $\begin{array}{llll}40 & 20 & 10 & 5\end{array}$ & $\begin{array}{llll}40 \quad 20 & 10 \quad 5\end{array}$ & $\begin{array}{llll}40 & 20 & 10 & 5\end{array}$ & 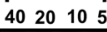 & 4020105 & $\begin{array}{llll}40 & 20 & 10 & 5\end{array}$ & 402010 & $\mathrm{PCNC}$ \\
\hline---- & -- & -- & $-\div$ & - & -1 & & $=$ \\
\hline
\end{tabular}

B

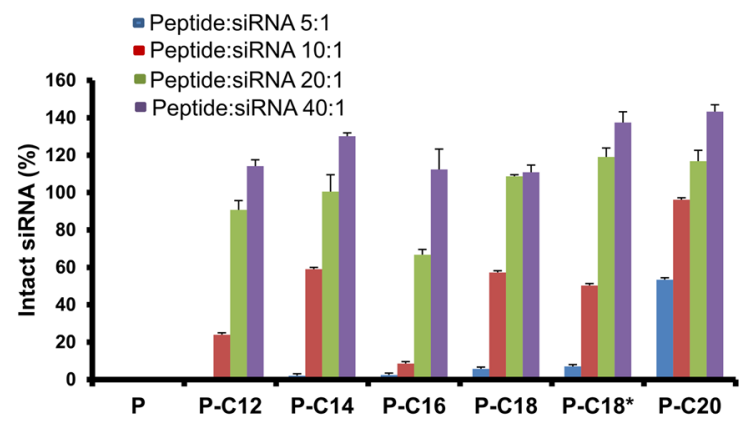

Figure 4. Serum stability of peptide:siRNA complexes. (A) Representative gel electrophoresis image of intact siRNA remaining after $24 \mathrm{~h}$ incubation with $25 \% \mathrm{FBS}$ at $37^{\circ} \mathrm{C}$. PC $=$ Positive Control representing free siRNA incubated with serum; $\mathrm{NC}=$ Negative Control (Quantified as 100\%) representing free siRNA incubated with saline; (B) Quantification of intact siRNA remaining after $24 \mathrm{~h}$ incubation. Complete protection was observed for all modified peptides at w/w ratio of 20:1 (N/P $\approx 27.3)$, except for P-C16, which achieved that at ratio of 40:1 $(\mathrm{N} / \mathrm{P} \approx 54.6)$ 
Peptides

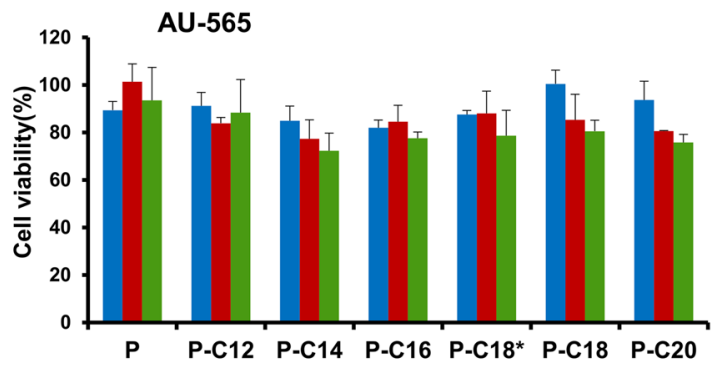

MDA-MB-435
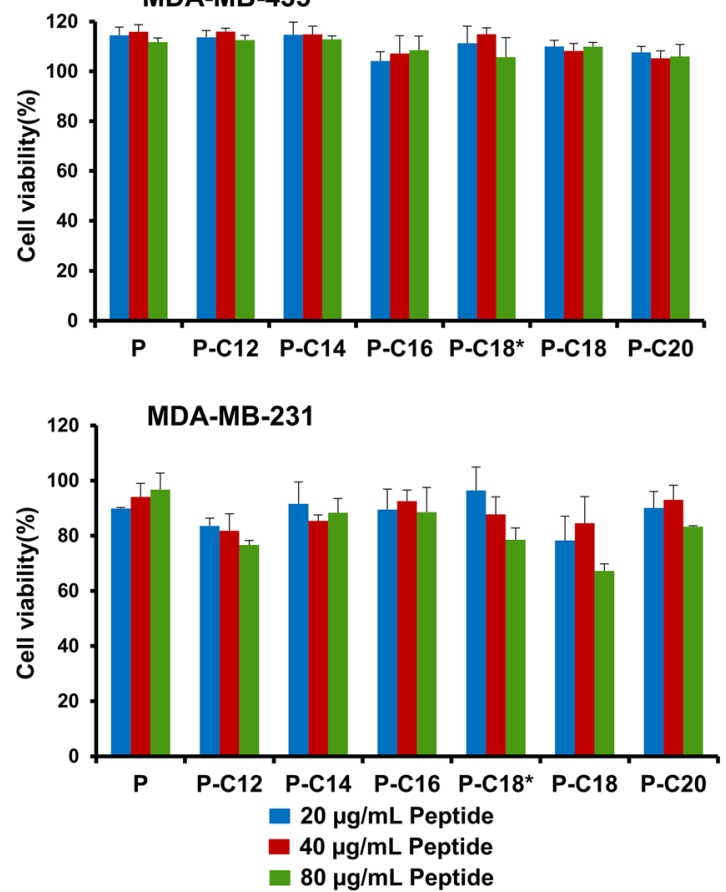

Peptide/siRNA Complexes
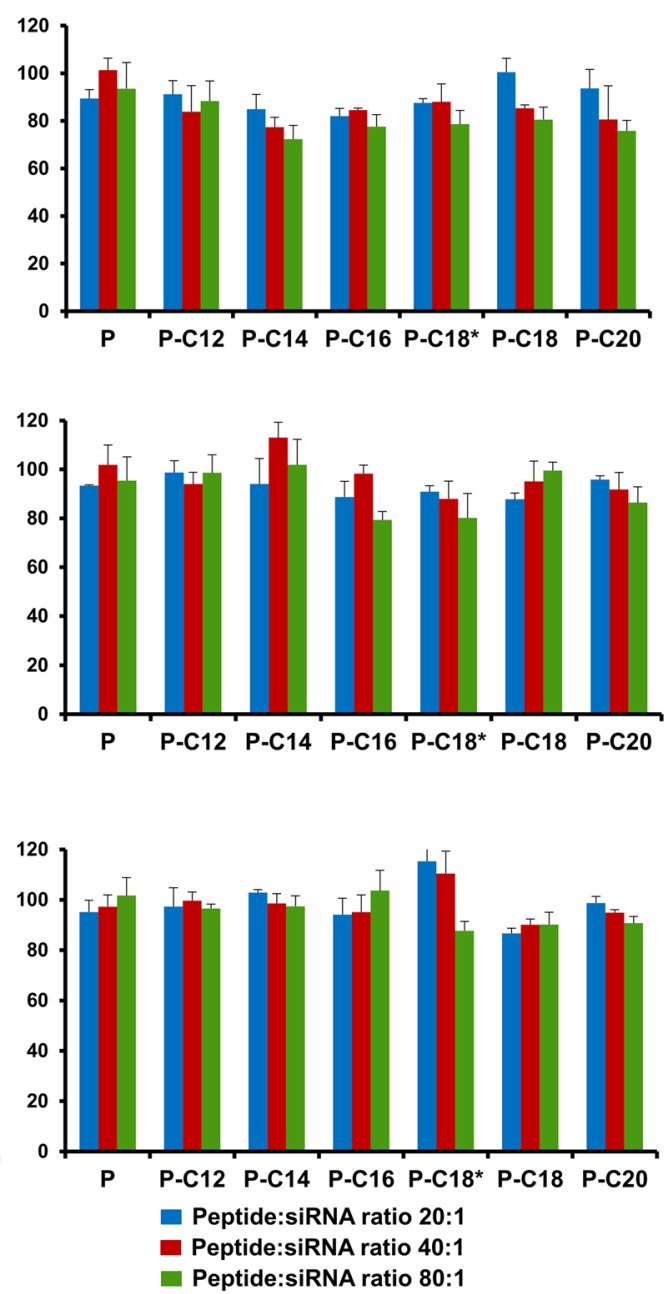

Figure 5. Cellular toxicity of peptides (left panels) and peptide/siRNA complexes (right panels). The viability of AU-565 cells, MDA-MB-435, and MDA-MB-231cells was evaluated using MTT assay after $72 \mathrm{~h}$ exposure to different concentration of peptides (left panels), or to complexes formed with scrambled siRNA and peptides at different peptide:siRNA w/w ratios. The percentage of viability is presented as Mean $+\mathrm{SD} ; \mathrm{n}=3$ ). No significant toxicity was observed for any of the studied peptides. For the similar experiment in HEK293 cells, see Supplementary Figure 1.

for MDA-MB-231 cells. However, the mean fluorescence better revealed the differences in delivery performance among the modified peptides (Fig. 6B). In AU-565 cells, oleic acid-conjugated peptide (P-C18*) created the highest mean fluorescent $(\sim 2900)$, and the ranking of the modified peptides in this cell line was: P-C18 $<$ P-C16 $<$ P$\mathrm{C} 14<\mathrm{P}-\mathrm{C} 12<\mathrm{P}-\mathrm{C} 20<\mathrm{P}-\mathrm{C} 18^{*}$. The overall pattern in the mean fluorescence in MDA-MB-435 cells was somewhat similar (with P-C12, P-C18*, and P-C20 demonstrating the highest mean fluorescent); however, the highest value was observed for lauric acid-conjugated peptide ( 3050), and the overall ranking in this cell line was: P-C $16<\mathrm{P}-\mathrm{C} 18<\mathrm{P}-\mathrm{C} 14<\mathrm{P}-\mathrm{C} 20<\mathrm{P}-\mathrm{C} 18^{*}<\mathrm{P}-\mathrm{C} 12$. As mentioned before, the overall mean fluorescence values in MDA-MB-231 cells were significantly lower, and the highest value was observed with P-C18* $(\sim 132)$. In this cell line, the modified peptides ranked as: $\mathrm{P}-\mathrm{C} 12=\mathrm{P}-\mathrm{C} 20=\mathrm{P}-\mathrm{C} 14<\mathrm{P}-\mathrm{C} 16<\mathrm{P}-\mathrm{C} 18<\mathrm{P}-\mathrm{C} 18 *$.

Since CGKRK is a tumor homing peptide, we compared the siRNA uptake by cancer cell lines with the non-tumorigenic embryonic kidney cell line (HEK293). Only the highest ratio was studied for this peptide, and even though some of the percentages of fluorescent-positive cells and mean fluorescence values were significantly different from the unmodified peptide, no significant difference was observed between "No Treatment", free siRNA, and unmodified peptide. Similarly, a significant correlation was not observed between number of carbons in the conjugated fatty acid and the generated mean fluorescent values (data not shown). The highest percentage of fluorescent-positive cells and the highest mean fluorescence value observed in this non-cancerous cell line were $\sim 9 \%$ and $99 \%$ (were free siRNA created mean fluorescence of $77 \%$ ), respectively (Fig. 6).

Samples of the cell populations and the recorded fluorescence graphs are also presented in Fig. 7A. Fluorescence microscopy was also used to confirm the intracellular delivery of FAM-labeled siRNA in different cell lines. Our previous experiments with confocal microscope has confirmed the intracellular localization of the 
A
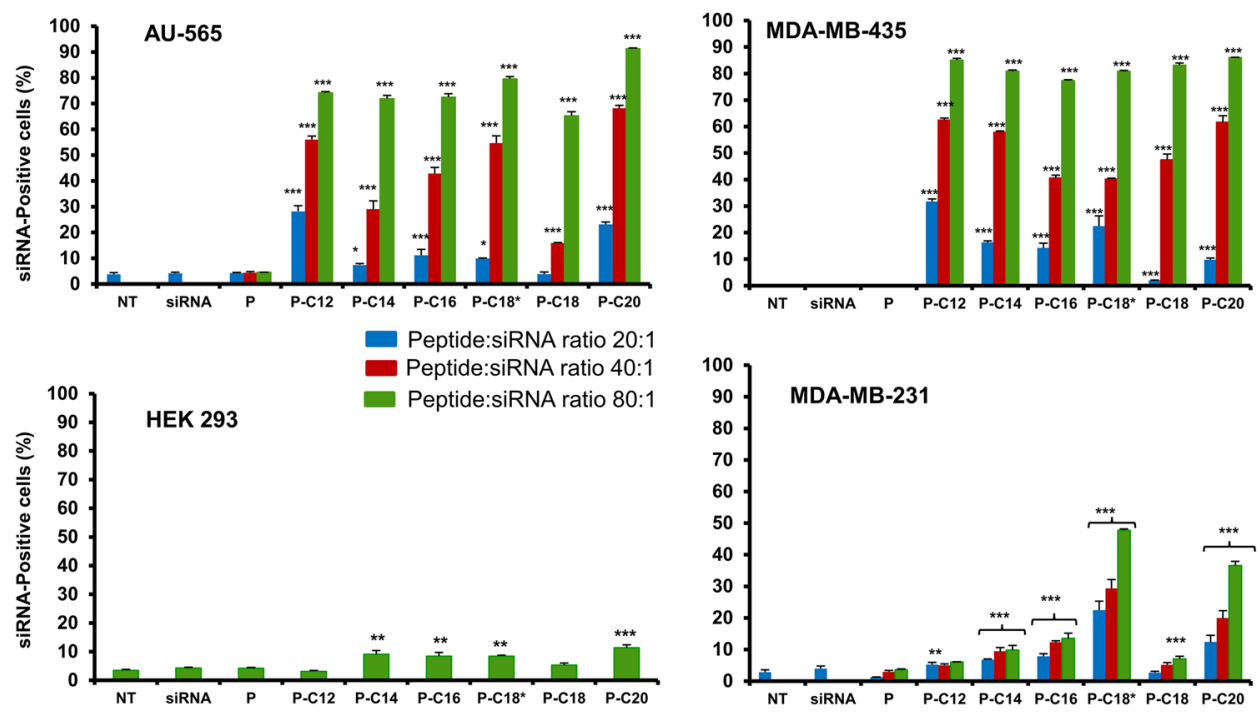

B
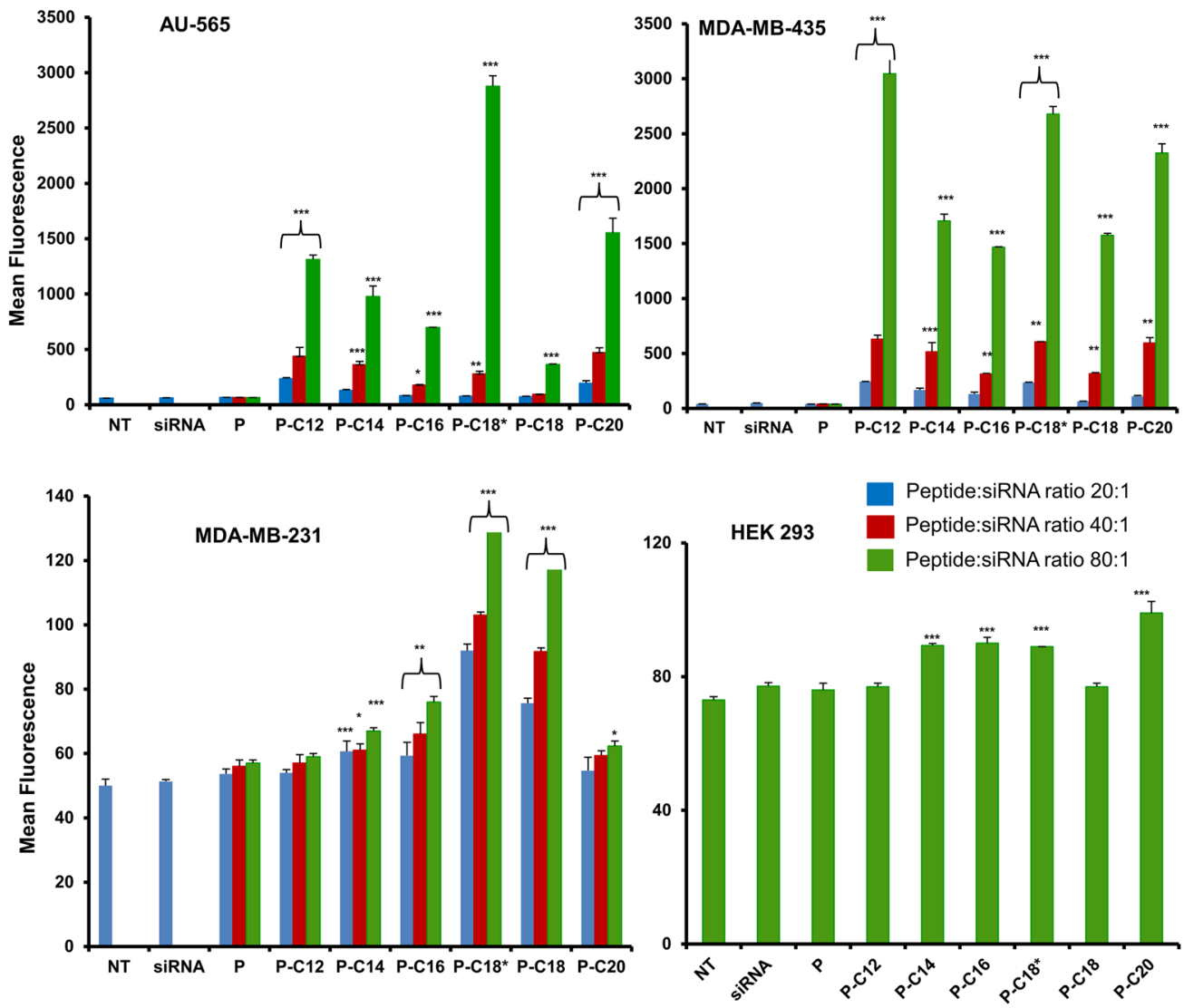

Figure 6. Cellular uptake of FAM-labelled siRNA. (A) The percentage of siRNA-positive cells for all the studied peptides at different peptide:siRNA w/w ratios. Modified peptides showed a significantly enhanced uptake compared to unmodified CGKRK, which continuously increased with higher ratios. No significant uptake was observed in normal HEK293 cells; (B) The extent of cellular internalization is also presented as the mean fluorescence of the whole cell population, which demonstrates the differences in siRNA uptake more efficiently. Overall, the extent of uptake was lower in the MDA-MB-231 cells compared to the other cancer cells included in this experiment. Uptake in HEK293 cells was negligible. In all graphs, data is shown as Mean $+D(n=3)$. $* * * \mathrm{p}<0.001 ; * * \mathrm{p}<0.01$; and $* \mathrm{p}<0.05$; calculated by the 2 -way ANOVA with Bonferroni post-test using Graph pad Prism software. 
delivered siRNA in cytoplasm ${ }^{11}$. We selected the oleic acid-conjugated peptide ( $\left.\mathrm{P}-\mathrm{C} 18^{*}\right)$ for these experiments, due to consistent efficiency for cellular internalization of siRNA in all the three cancer cell lines. Images are presented with blue (for DAPI used to stain the nucleus), red (for Texas Red Phalloidin used to stain cell membrane), and green (for FAM label conjugated to the scrambled siRNA) channels separately, and merged (Fig. 7B). The images confirmed significant fluorescent signal for labeled siRNA inside the cytoplasm of all three cancer cell lines.

Silencing Efficiency. The functional performance of the fatty acid-conjugated peptides was evaluated based on the silencing efficiency of a model protein (Kinesin spindle protein; KSP) as evaluated by real-time PCR. A sample of amplification graphs observed is shown in Fig. 8A. The silencing experiments were conducted in AU-565 cells, with all the modified peptides with peptide:siRNA ratio of 80:1 (N/P $\approx 109)$. The level of targeted mRNA (normalized based on the selected endogenous gene, $\beta$-actin) was significantly lowered via siRNA delivery by all the modified peptides, compared to cell exposed to complexes formed by the corresponding peptide and scrambled siRNA (Fig. $8 \mathrm{~B}$ ). The most significant effect was observed with PC-18* (RQ $\approx 0.58)$, where the mRNA level was significantly lower (with different $P$ values) than other modified peptides.

\section{Discussion}

This study was designed to analyze the effect of the hydrophobic modification on the characteristics of CGKRK peptide for siRNA delivery. This pentapeptide (Cys - Gly - Lys - Arg - Lys) has been shown to target tumor vasculature in glioblastoma ${ }^{28}$, breast cancer ${ }^{29}$, and an epidermal carcinogenesis animal model ${ }^{25}$. CGKRK has been used as the targeting moiety in polyethylene glycol - poly( $\varepsilon$-caprolactone) (PEG-co-PCL) nanoparticles to target tumor angiogenic blood vessels and human U87MG tumor cells ${ }^{24}$. Linked with PEG, it has also been studied as the targeting moiety for an adenoviral vector used for cancer gene therapy ${ }^{30}$. It has been reported that fatty acid conjugation to the therapeutic agents (e.g. protein, peptides, and siRNA) helps in improving the stability of the therapeutic agents in the blood ${ }^{31-33}$. We selected a range of different fatty acids for conjugation to CGKRK. Our previous experience indicates that smaller fatty acids might lack the significant impact on the carrier efficiency, and larger than 20 carbon chain length might limit the water solubility significantly, which in turn could negatively impact the efficacy of the delivery ${ }^{12}$. Therefore we selected fatty acid ranging from 12 to 20 carbon chain length. Fatty acylation was achieved on solid phase during peptide synthesis using mild condition in a quantitative yield. All the peptides were purified by using reverse phase HPLC and characterized by higher resolution MALDI mass spectrometer (see supplementary information). The peptides used in the study had $>95 \%$ purity.

Without the proposed hydrophobic modification, CGKRK did not readily interact with siRNA. A reduction in the size of complexes and a gradual shift in the surface charge from negative to positive values are among the signs of the ionic interaction between the carrier and siRNA, which were both observed for all of the modified peptides (Fig. 3A and B). The significant drop in particle size with changing the peptide:siRNA ratio from 1:1 $(\mathrm{N} / \mathrm{P} \approx 1.4)$ to $5: 5(\mathrm{~N} / \mathrm{P} \approx 6.8)$ indicates condensed nucleotides associated with the complex formation, while the positive $\zeta$-potential is a sign of incorporation of more positively charged peptides into the complex, which shifts the overall surface charge of the particle. Although a size of $\sim 100 \mathrm{nM}$ seems to be an optimal size for delivery systems, effective in vitro uptake has been reported for particles as large as $200 \mathrm{nM}$ or higher ${ }^{7}$. It has been reported that hydrophobic modification of siRNA carriers could increase the overall $\zeta$-potential of the complexes. We speculate that a possible explanation for this observation is the hydrophobic barrier that forms with fatty-acid conjugated carrier. The $\zeta$-potential is not quantified at the actual surface of the particle, but at the tightly bound layer, where the ions in the aqueous solution neutralize some of the electrical charge of the particle. Therefore, a hydrophobic component could form a barrier at the tightly bound layer, preventing this neutralization of charges, which would result in a more positive $\zeta$-potential for the complexes formed with the hydrophobically modified peptide. Regardless of the mechanism, this positive $\zeta$-potential would also further contribute to the higher cellular internalization efficacy with modified peptides.

This lack of proper interaction between unmodified peptide and siRNA was also confirmed by our binding affinity and serum stability experiments. While all conjugated peptides approached complete siRNA binding at peptide:siRNA ratios of 1:2.5 to 1:5, the siRNA binding affinity of the unmodified peptide plateaued well below values observed for modified peptides. We have previously reported a slight decrease in binding affinity of low molecular polyethyleneimine (PEI; with significant binding affinity to nucleotides) as a result of hydrophobic modification $^{12}$, which seems to be expected due to increasing in hydrophobicity of the carrier. Despite initial affinity observed for the unmodified peptide in lower peptide:siRNA ratios, the binding was never completed. A slight increase was observed in the calculated BC50s (the peptide:siRNA ratio required for $50 \%$ binding), and P-C20 showed the highest BC50, which indicates the lowest affinity with the most hydrophobic modification. However, no significant correlation between BC50 and the size of the fatty acids was observed, mostly due to the unexpected high affinity of peptides modified with fatty acids with 18 carbon chain length (PC-18 and PC18*; Fig. 3D).

siRNA is instantly degraded in vivo (or even in cell culture) by RNase A-type nucleases ${ }^{34}$. In fact, this susceptibility to enzymatic degradation plays a major role in the extremely short serum half-life for siRNA, which has been reported as less than $30 \mathrm{~min}^{35}$. Therefore, one of the characteristics of an efficient siRNA carrier is its ability to protect siRNA from early degradation. Based on the $\zeta$-potential quantifications, we expected significant protection against enzymatic degradation for all the modified peptides. An overall positive charge for the peptide/ siRNA complexes indicates the complete binding, neutralization of negative charge, and condensation of siRNA, which indicates completion of the complex formation. The condensed complexes are expected to withstand exposure to degrading enzymes for extended periods of time. We validated the efficiency of our serum stability test by negative (exposing free siRNA to saline) and positive (exposing free siRNA to serum) controls, which confirmed full stability in the absence of serum and efficient enzymatic degradation in the presence of serum, respectively. 


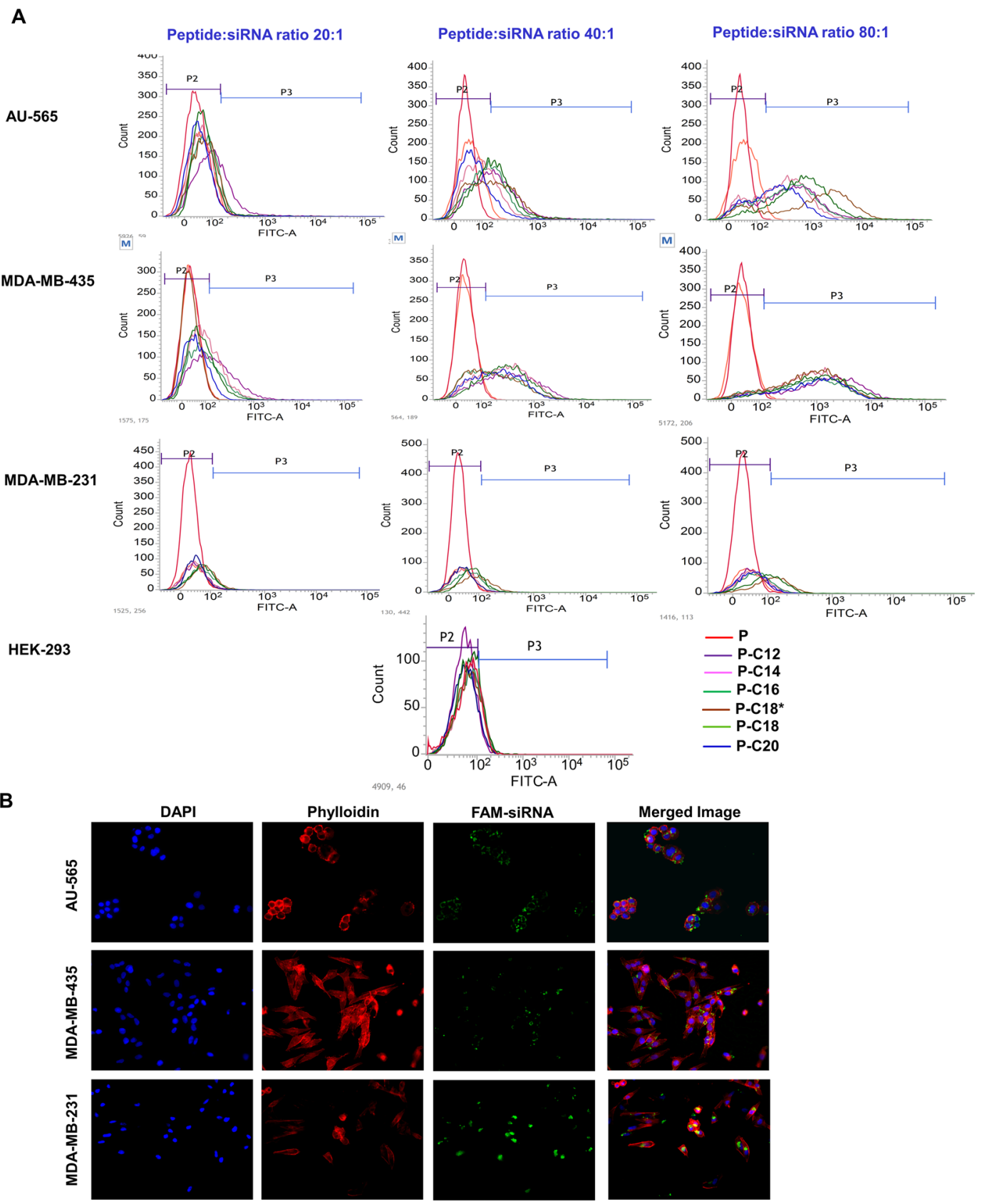

Figure 7. Visualization of uptake of FAM-siRNA. (A) Samples of the fluorescence signal for the cell populations for AU565, MDA-MB-435, and MDA-MB-231 cells after 24h exposure to peptide:FAM-labelled siRNAs at w/w ratios of 20:1, 40:1, and 80:1 (N/P $\approx 27.3,54.6$, and 109, respectively, from left to right). Gates $\mathrm{P} 2$ and $\mathrm{P} 3$ represent fluorescence of un-treated and FAM-labelled siRNA treated cells, respectively. (B) Fluorescent microscope images (KEYENCE BZ-X700 all-in-one Fluorescence Microscope; Itasca, IL, USA) demonstrating (from left to right) DAPI-stained nuclei, Texas Red Phalloidin-stained cell membrane, FAM-labelled siRNA, and the merged images from AU565, MDA-MB-435, and MDA-MB-231 cells, after $24 \mathrm{~h}$ exposure to complexes formed with P-C18* peptide:FAM-labelled scrambled siRNA with w/w ratio of 80:1 (N/P $\approx 109)$.

As expected by negative $\zeta$-potential and incomplete binding, unmodified peptide offered no detectable protection against enzymatic degradation, similar to free siRNA (Fig. 4). On the other hand, our all fatty acid-modified peptides protected siRNA from the serum degradation. This is similar to the results reported by Li Y et al. ${ }^{36}$, which indicates improvement in stability and binding affinity of glucagon like peptide-1(GLP-1) after conjugation with the fatty acid-like molecules. Although all the peptide conjugates offered protection against the serum degradation at highest peptide:siRNA ratio, $\mathrm{P}-\mathrm{C} 20$ was the only modified peptide that offered any significant protection at the lowest peptide:siRNA ratio tested $(5: 1 ; \mathrm{N} / \mathrm{P} \approx 6.8)$, which could be explained by the highest hydrophobicity (and the least interaction with the aqueous environment) of this carrier among the studied peptides. 


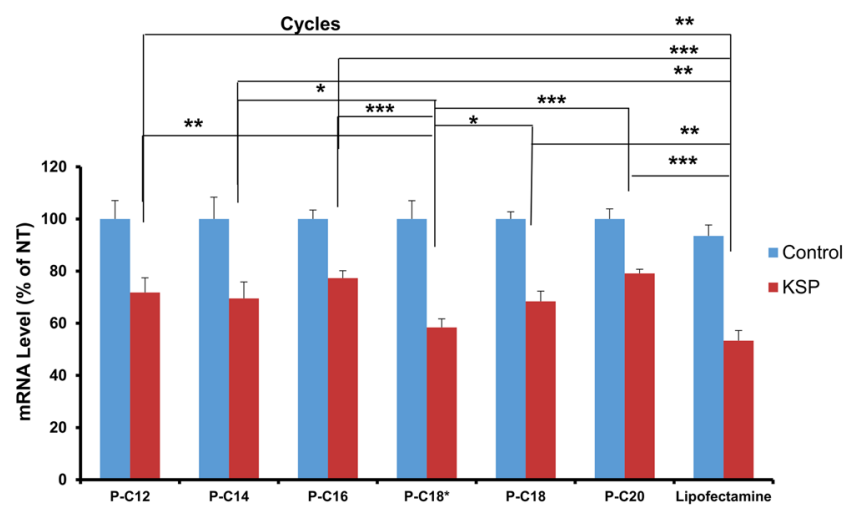

Figure 8. Quantification of down-regulation of KSP mRNA. Real-time PCR analysis of KSP expression (normalized based on beta actin) in AU-565 cells treated with scrambled (control) or KSP siRNA represented as mean $+\mathrm{SD}(\mathrm{n}=3)$, after $48 \mathrm{~h}$ of exposure to peptide/siRNA complexes (w/w ratio of $80: 1 ; \mathrm{N} / \mathrm{P} \approx 109$ ) prepared with the modified peptides. The asterisks $(*, * *, * * *)$ represent significant difference at levels of $\mathrm{P}<0.05,0.01$, and 0.001 , respectively.

The success of many promising siRNA delivery systems has been marred due to unacceptable toxicity. It has been speculated that potential toxicity of positively charged siRNA carriers could be due to transient nano-sized holes in the cytoplasmic membrane, which could also be partially responsible for enhanced cellular uptake ${ }^{37}$. Complex formation, on the other hand, will change the overall surface charge of the particles interacting with the cell membrane, due to partial neutralization of the charges. For that reason, we selected two approaches to evaluate the potential toxicity of the synthesized peptides: first, exposing the cells to peptides, and second exposure of cells to peptide/siRNA complexes. We also selected four different cell lines (three cancer cell lines, plus HEK293 cells) to evaluate the consistency of the results in a wider range of cell types. In this study, however, neither a significant toxicity nor a trend was observed for any of the peptides in the selected cell lines, via these two approaches. This was expected since no significant cytotoxicity has been reported for the unmodified peptide.

The site of action for siRNA is cytoplasm, and therefore, cellular internalization is a crucial step for reliable and reproducible silencing efficiency. However, free siRNA has little chance for significant internalization due to its chemical characteristics. Many different strategies have shown promising results in siRNA cellular uptake, including cell binding ligands and using hydrophobic components (which was the basis for our hydrophobic modification hypothesis). Although active targeting moieties, including CGKRK, have been mainly used to enhance the accumulation of their cargo in the target tissue or cells, they may also increase the cellular uptake of siRNA by enhancing interaction with the cell membrane, which seems to be required for effective internalization. For instance, a study in NOD/SCID mice showed comparable accumulation of siRNA in Neuro2 xenograft tumor with targeted and non-targeted nanoparticles; however, the silencing efficiency was almost doubled with the use of transferrin as the targeting ligand, which indicates an enhanced uptake ${ }^{38}$. The same beneficiary effect has been reported for $\mathrm{K}_{16}$ GACYGLPHKFCG peptide in cationic liposomes ${ }^{39}$, 40, folate in polymeric delivery systems ${ }^{41,42}$, and "mannosylated" polymer that interacts with mannose receptors ${ }^{43}$. While free siRNA did not show any detectable internalization in any of the selected cell lines as expected, it was interesting that complexes formed with unmodified peptide did not improve the uptake either (Figs 6 and 7). This is, however, explained by the incomplete and inefficient complex formation, negative $\zeta$-potential, and the lack of serum stability for siRNA delivered with unmodified peptide. The modified fatty acid-conjugated peptides, on the other hand, showed significant improvement in siRNA uptake in all selected cancer cell lines, which continually increased with higher peptide:siRNA ratio. We have previously reported a similar pattern for the uptake of siRNA complexes with hydrophobically-modified PEIs with different polymer:siRNA ratios ${ }^{12,44,45}$. No specific trend was observed for the effect of fatty acid size on the siRNA uptake. It is noteworthy that none of the studied peptides induced significant internalization in the non-tumorigenic HEK293 cells. CGKRK peptide was discovered after multiple rounds of phage display ${ }^{25}$, which specifically binds to the neurovascular endothelial cells using heparan sulfate receptor. The expression of this receptor is little to none in the HEK293 cells ${ }^{46}$ due to non-malignant nature of these cells. Heparan sulfate receptors are sulfate polysaccharides, which present in neovascular endothelial cells and tumor cells specifically ${ }^{26}$.

Cellular internalization does not guaranty effective silencing. Depending on the route of internalization, particles could be trapped and degraded on their way to the cytoplasm. For example, in the case of endocytosis, siRNA/ carrier needs to escape the endosome by non-contact mechanisms (that could involve endosomal eruption; e.g., "proton sponge effect") ${ }^{47}$, or direct interaction of the carrier with the endosomal bilayer membrane. Also, after entering the cytoplasm, the siRNA would only be functional if it is released from the carrier in a timely manner. In fact, the disassembly of the carrier/siRNA package could become a major barrier for efficient silencing ${ }^{39,48}$. Therefore, our final step in this project was to demonstrate effective interference with the selected mRNA in a cancer cell line. We selected kinesin spindle protein (KSP) for this purpose, due to its relevance to cancer therapy. This protein is involved in centrosome separation and bipolar spindle assembly, and silencing KSP has shown positive effect on suppression of subcutaneous melanomas and ovarian tumors ${ }^{49}$. An effective down-regulation of KSP mRNA levels was observed for all modified peptides in the real-time PCR analysis (Fig. 8). This effect was 
the most significant for P-C18*, which showed the most efficient cellular internalization in AU565 cells as well. Interfering with KSP mRNA with Lipofectamine ${ }^{\circledR} 2000$, as a widely used commercial siRNA transfecting agent, resulted in a RQ of 53.3, which was not statistically different than the efficiency of P-C18*. This observation confirms our findings in cellular internalization analysis and the proper cytoplasmic delivery of siRNA by oleic acid-conjugated CGKRK peptide.

\section{Conclusions}

In this study, we have demonstrated the development of a tumor-targeted delivery system using fatty acylation of CGKRK peptide. Fatty acylation was carried out using various fatty acids (C12 to C20 including unsaturated C18 oleic acid) during peptide synthesis with excellent yield. The characterization studies revealed complex formation with siRNA for all modified peptides, which showed significant binding affinity to siRNA and promising capability in protecting siRNA against early degradation. Safe and effective intracellular delivery of siRNA was also confirmed by cytotoxicity and cellular uptake experiments, respectively. However, no significant cellular uptake was detected in human non-tumorigenic cells for any of the modified peptides, which is important to confirm tumor specificity of the designed delivery systems. Efficient interference with the mRNA of an important protein involved in cancer cell proliferation indicates potential applications of the fatty acid-conjugated CGKRK as a tumor-specific siRNA carrier.

\section{References}

1. Blackburn, E. H. et al. World Cancer Report 2014. W.H.O. 2014.

2. American Cancer Society. Cancer Facts \& Figures 2016. Atlanta: American Cancer Society. http://www.cancer.org/research/ cancerfactsstatistics/cancerfactsfigures2016/.

3. Fire, A. et al. Potent and specific genetic interference by double-stranded RNA in Caenorhabditis elegans. Nature 391, 806-811 (1998).

4. Mansoori, B., Sandoghchian Shotorbani, S. \& Baradaran, B. RNA interference and its role in cancer therapy. Adv. Pharm. Bull. 4, 313-321 (2014).

5. Malone, C. D. \& Hannon, G. J. Small RNAs as guardians of the genome. Cell 136, 656-668 (2009).

6. Ghildiyal, M. \& Zamore, P. D. Small silencing RNAs: an expanding universe. Nat. Rev. Genet. 10, 94-108 (2009).

7. Aliabadi, H. M., Landry, B., Sun, C., Tang, T. \& Uludag, H. Supramolecular assemblies in functional siRNA delivery: where do we stand? Biomaterials 33, 2546-2569 (2012).

8. Fire, A. Z. Gene silencing by double-stranded RNA. Cell Death Differ. 14, 1998-2012 (2007).

9. Alexis, F., Pridgen, E., Molnar, L. K. \& Farokhzad, O. C. Factors affecting the clearance and biodistribution of polymeric nanoparticles. Mol. Pharm. 5, 505-515 (2008).

10. Valencia-Serna, J., Gul-Uludag, H., Mahdipoor, P., Jiang, X. \& Uludag, H. Investigating siRNA delivery to chronic myeloid leukemia K562 cells with lipophilic polymers for therapeutic BCR-ABL down-regulation. J. Control. Rel. 172, 495-503 (2013).

11. Landry, B. et al. Effective non-viral delivery of siRNA to acute myeloid leukemia cells with lipid-substituted polyethylenimines. PLoS One 7, e44197 (2012).

12. Aliabadi, H. M. et al. Impact of lipid substitution on assembly and delivery of siRNA by cationic polymers. Macromol. Biosci. 11, 662-672 (2011)

13. Xia, C. F., Zhang, Y., Zhang, Y., Boado, R. J. \& Pardridge, W. M. Intravenous siRNA of brain cancer with receptor targeting and avidin-biotin technology. Pharm. Res. 24, 2309-2316 (2007).

14. Chu, T. C., Twu, K. Y., Ellington, A. D. \& Levy, M. Aptamer mediated siRNA delivery. Nucleic Acids Res. 34, e73 (2006).

15. Hayes, M. E. et al. Assembly of nucleic acid-lipid nanoparticles from aqueous-organic monophases. Biochim. Biophys. Acta 1758, 429-442 (2006).

16. Khoury, M. et al. Efficient new cationic liposome formulation for systemic delivery of small interfering RNA silencing tumor necrosis factor alpha in experimental arthritis. Arthritis Rheum. 54, 1867-1877 (2006).

17. Zuhorn, I. S. et al. Phase behavior of cationic amphiphiles and their mixtures with helper lipid influences lipoplex shape, DNA translocation, and transfection efficiency. Biophys. J. 83, 2096-2108 (2002).

18. Shirazi, A. N., Paquin, K. L., Howlett, N. G., Mandal, D. \& Parang, K. Cyclic peptide-capped gold nanoparticles for enhanced siRNA delivery. Molecules 19, 13319-13331 (2014).

19. Jafari, M. et al. Serum stability and physicochemical characterization of a novel amphipathic peptide C6M1 for siRNA delivery. PLoS One 9, e97797 (2014).

20. Zhang, S., Zhao, B., Jiang, H., Wang, B. \& Ma, B. Cationic lipids and polymers mediated vectors for delivery of siRNA. J. Control Rel. 123, 1-10 (2007).

21. Navarro, G. et al. Phospholipid-modified polyethylenimine-based nanopreparations for siRNA-mediated gene silencing: implications for transfection and the role of lipid components. Nanomedicine 10, 411-419 (2014).

22. Liu, Z. H., Zhang, Z. Y., Zhou, C. R. \& Jiao, Y. P. Hydrophobic modifications of cationic polymers for gene delivery. Prog. Polym. Sci. 35, 1144-1162 (2010).

23. Layek, B. \& Singh, J. Amino acid grafted chitosan for high performance gene delivery: comparison of amino acid hydrophobicity on vector and polyplex characteristics. Biomacromolecules 14, 485-494 (2013).

24. $\mathrm{Hu}, \mathrm{Q}$. et al. CGKRK-modified nanoparticles for dual-targeting drug delivery to tumor cells and angiogenic blood vessels. Biomaterials 34, 9496-9508 (2013).

25. Hoffman, J. A. et al. Progressive vascular changes in a transgenic mouse model of squamous cell carcinoma. Cancer Cell 4, 383-391 (2003).

26. Jarvinen, T. A. \& Ruoslahti, E. Molecular changes in the vasculature of injured tissues. Am. J. Pathol. 171, 702-11 (2007).

27. Oh, D. et al. Enhanced cellular uptake of short polyarginine peptides through fatty acylation and cyclization. Mol. Pharm. 11, 2845-2854 (2014).

28. Agemy, L. et al. Targeted nanoparticle enhanced proapoptotic peptide as potential therapy for glioblastoma. Proc. Natl. Acad. Sci. USA 108, 17450-17455 (2011).

29. Agemy, L. et al. Proapoptotic peptide-mediated cancer therapy targeted to cell surface p32. Mol. Ther. 21, 2195-2204 (2013).

30. Yao, X. L. et al. Optimization and internalization mechanisms of PEGylated adenovirus vector with targeting peptide for cancer gene therapy. Biomacromolecules 13, 2402-2409 (2012).

31. Kratz, F. Albumin as a drug carrier: design of prodrugs, drug conjugates and nanoparticles. J. Control. ReL. 132, 171-183 (2008).

32. Hackett, M. J., Joolakanti, S., Hartranft, M. E., Guley, P. C. \& Cho, M. J. A dicarboxylic fatty acid derivative of paclitaxel for albuminassisted drug delivery. J. Pharm. Sci. 101, 3292-3304 (2012).

33. Ashrafi, H. et al. Nanostructure L-asparaginase-fatty acid bioconjugate: synthesis, preformulation study and biological assessment. Int. J. Biol. Macromol. 62, 180-187 (2013). 
34. Haupenthal, J., Baehr, C., Kiermayer, S., Zeuzem, S. \& Piiper, A. Inhibition of RNAse A family enzymes prevents degradation and loss of silencing activity of siRNAs in serum. Biochem. Pharmacol. 71, 702-710 (2006).

35. Raemdonck, K., Vandenbroucke, R. E., Demeester, J., Sanders, N. N. \& De Smedt, S. C. Maintaining the silence: reflections on longterm RNAi. Drug Discov. Today 13, 917-931 (2008).

36. Li, Y. et al. Variant fatty acid-like molecules Conjugation, novel approaches for extending the stability of therapeutic peptides. Sci. Rep. 5, 18039 (2015).

37. Hong, S. et al. Interaction of polycationic polymers with supported lipid bilayers and cells: nanoscale hole formation and enhanced membrane permeability. Bioconjug. Chem. 17, 728-734 (2006)

38. Bartlett, D. W., Su, H., Hildebrandt, I. J., Weber, W. A. \& Davis, M. E. Impact of tumor-specific targeting on the biodistribution and efficacy of siRNA nanoparticles measured by multimodality in vivo imaging. Proc. Natl. Acad. Sci. USA 104, 15549-15554 (2007).

39. Tagalakis, A. D., He, L., Saraiva, L., Gustafsson, K. T. \& Hart, S. L. Receptor-targeted liposome-peptide nanocomplexes for siRNA delivery. Biomaterials 32, 6302-6315 (2011).

40. Tagalakis, A. D. et al. Multifunctional, self-assembling anionic peptide-lipid nanocomplexes for targeted siRNA delivery. Biomaterials 35, 8406-8415 (2014).

41. Cheng, C. J. \& Saltzman, W. M. Enhanced siRNA delivery into cells by exploiting the synergy between targeting ligands and cellpenetrating peptides. Biomaterials 32, 6194-6203 (2011)

42. Dong, D. W. et al. $\mathrm{pH}$-responsive complexes using prefunctionalized polymers for synchronous delivery of doxorubicin and siRNA to cancer cells. Biomaterials 34, 4849-4859 (2013).

43. Yu, S. S. et al. Macrophage-specific RNA interference targeting via "click", mannosylated polymeric micelles. Mol. Pharm. 10, 975-987 (2013)

44. Aliabadi, H. M., Landry, B., Mahdipoor, P., Hsu, C. Y. \& Uludag, H. Effective down-regulation of breast cancer resistance protein (BCRP) by siRNA delivery using lipid-substituted aliphatic polymers. Eur. J. Pharm. Biopharm. 81, 33-42 (2012).

45. Aliabadi, H. M. et al. Effective response of doxorubicin-sensitive and -resistant breast cancer cells to combinational siRNA therapy. J. Control. Rel. 172, 219-228 (2013).

46. Lee, S., Kim, M. G., Kim, N., Do Heo, W. \& Lee, G. M. Heparan sulfate proteoglycan synthesis in CHO DG44 and HEK293 cells. Biotechnol. Bioproc. E. 21, 439-445 (2016).

47. Boussif, O. et al. A versatile vector for gene and oligonucleotide transfer into cells in culture and in vivo: polyethylenimine. Proc. Natl. Acad. Sci. USA 92, 7297-7301 (1995).

48. Huth, S. et al. Interaction of polyamine gene vectors with RNA leads to the dissociation of plasmid DNA-carrier complexes. J. Gene Med. 8, 1416-1424 (2006).

49. Marra, E., Palombo, F., Ciliberto, G. \& Aurisicchio, L. Kinesin spindle protein SiRNA slows tumor progression. J. Cell Physiol. 228, 58-64 (2013)

\section{Acknowledgements}

The authors greatly acknowledge financial support for this research from Chapman University School of Pharmacy. The authors have no conflicts of interest to declare. This paper is dedicated to the memory of the late Professor Abbas Shafiee, our beloved and wonderful teacher in Organic and Medicinal Chemistry.

\section{Author Contributions}

M.S., R.K.T. and H.M.A. conceived and designed the study; N.S.El-S. and H.D. synthesized the peptides; M.S. performed all the experiments; K.P. provided the HEK293 cell lines; M.S., K.P., R.K.T. and H.M.A. analyzed the data and wrote the manuscript.

\section{Additional Information}

Supplementary information accompanies this paper at doi:10.1038/s41598-017-06381-y

Competing Interests: The authors declare that they have no competing interests.

Publisher's note: Springer Nature remains neutral with regard to jurisdictional claims in published maps and institutional affiliations.

(i) Open Access This article is licensed under a Creative Commons Attribution 4.0 International cc. License, which permits use, sharing, adaptation, distribution and reproduction in any medium or format, as long as you give appropriate credit to the original author(s) and the source, provide a link to the Creative Commons license, and indicate if changes were made. The images or other third party material in this article are included in the article's Creative Commons license, unless indicated otherwise in a credit line to the material. If material is not included in the article's Creative Commons license and your intended use is not permitted by statutory regulation or exceeds the permitted use, you will need to obtain permission directly from the copyright holder. To view a copy of this license, visit http://creativecommons.org/licenses/by/4.0/.

(C) The Author(s) 2017 